\title{
FLASH PYROLYSIS OF FUSHUN OIL SHALE FINE PARTICLES IN AN EXPERIMENTAL FLUIDIZED-BED REACTOR
}

\author{
MINGDONG CHEN $^{(\mathrm{a}) *}$, YULIANG SHI ${ }^{(\mathrm{a})}$, \\ LIANGJIE DONG $^{(\mathrm{b})}$, QI WANG ${ }^{(\mathrm{b})}$
}

(a) College of Architecture Engineering, Qingdao Agricultural University Qingdao 266109, Shandong, China

(b) College of Engineering and Technology, Jilin Agricultural University Changchun 130118, Jilin, China

\begin{abstract}
Oil shale screenings ( $d \leq 10 \mathrm{~mm})$, not used for the Fushun retort in the Fushun retorting plant of China, were crushed and sieved to different fractions of fine particles (in the range of 0-0.95 $\mathrm{mm}$ ) which were pyrolysed in an experimental fluidized-bed reactor developed by the Institute of Comprehensive Utilization of Waste, Jilin Agricultural University. The optimum pyrolysis parameters of fine-particle oil shale were determined via orthogonal experiments, and one-factor experiment was performed to verify the results of the orthogonal experiments. The effects of oil shale particle size, feeding rate and reaction temperature on the yield of shale oil were analyzed. The results showed that the yield of shale oil reached $5.13 \%$ under the optimum experiment conditions, and the optimum combination was as follows: particle size of oil shale less than $0.47 \mathrm{~mm}$; feeding rate $14 \mathrm{~kg} / \mathrm{h}$ (residence time $11 \mathrm{~min}$ ) and reactor temperature $450-500{ }^{\circ} \mathrm{C}$. Experimental parameters of flash pyrolysis of oil shale fine particles will provide theoretical basis for utilizing shale screenings of retorting plant.
\end{abstract}

\section{Introduction}

Oil shale is one kind of fossil fuel and its abundant reserves are the second largest among all fossil fuels in the world if converted into heat [1]. The deposits of oil shale are distributed throughout the world, though unevenly. As of the end of 2005, the published statistics show that the oil equivalent reserves of oil shale in 37 countries of the world are about $410 \mathrm{Gt}$, which are estimated to be much greater than crude oil reserves [2]. After thorough explorations, the proven oil shale reserves in the United States are the largest

*Corresponding author: e-mail mingdong3202@126.com 
in the world, followed by Russia, Zaire, Brazil, Canada, Jordan, Australia and China [3-8]. The proven shale oil reserves of these eight countries are as follows $(\mathrm{Gt})$ :

United States 300; Russia 39; Zaire 14; Brazil 12; Canada 6.3; Jordan 4.8; Australia 2.9; China 2.4.

The history of oil shale industry stretches over 200 years, but the process of development and utilization of oil shale has been hindered by serious technical, economic and environmental problems [9]. However, regarding shale oil as one of the largest sources of hydrocarbons [2], it is time to work harder at the development and utilization of oil shale in the time of serious energy shortage. At present, shale oil is in several countries produced by retorting oil shale, and most of the technologies require production of shale oil from lump oil shale of larger size, such as Fushun-type retort in China, Kiviter retort in Estonia, and Petrosix retort in Brazil. The utilization of undersize screenings at a retorting plant is scarce, except Estonian Galoter process and Canadian ATP process [10]. Therefore, it is a rewarding task to find an effective means to produce shale oil from retorting plant screenings. The fluidized-bed reactor with a fast heating rate, short residence time, simple temperature control, convenient recycling of solids and lower investment has become the appropriate potential device among all pyrolysis devices. A flash pyrolysis experiment of oil shale fine particles in the range of $0-0.95 \mathrm{~mm}$ (obtained from crushing and sieving of the Fushun oil shale screenings, with the size of less than $10 \mathrm{~mm}$, discarded by the shale oil plant) was conducted in the fluidized-bed reactor, developed by Jilin Agricultural University Lab, China, and satisfactory experimental results can provide the theoretical basis for fluidized-bed pyrolysis of raw shale screenings.

\section{Materials and methods}

\section{Materials}

In China, the deposits of oil shale are mainly distributed in Fushun, Maoming, Huadian and Huangxian. The data on elemental analysis of Chinese oil shales are shown in Table 1 [11]. Oil shale samples $(0-10 \mathrm{~mm})$, discarded by the Fushun retorting plant of China, were crushed by a jaw crusher and sieved into six fractions $(\mathrm{mm})$ : $0-0.3 ; 0.3-0.47 ; 0.47-0.61$; $0.61-0.67$; 0.67-0.78; and 0.78-0.95.

Quartz sand as heat carrier was packed in the fluidized-bed reactor to a height of $20 \mathrm{~cm}$ and heated up to a temperature $20-30{ }^{\circ} \mathrm{C}$ above the selected reaction temperature in advance. The sand would mix with and heat the incoming cold oil shale particles instantly to a constant reaction temperature. In accordance with the design parameters of the fluidized-bed reactor, we selected quartz sand of the size and density $0.4-0.67 \mathrm{~mm}$ and $2.3 \mathrm{~g} / \mathrm{cm}^{3}$ respectively for the experiment. Quartz sand of such a density would not be carried out with the exit two-phase stream from the reactor remaining the heat carrier. 
Table 1. Elemental analysis (\% by weight) of Chinese oil shale

\begin{tabular}{|l|c|c|c|c|c|c|}
\hline Deposition & Yield of shale oil & $\mathrm{C}$ & $\mathrm{H}$ & $\mathrm{S}$ & $\mathrm{N}$ & Ash \\
\hline Fushun & 6.3 & 13.77 & 2.29 & 0.59 & 0.51 & 72.77 \\
Maoming & 7.3 & 14.82 & 2.51 & 1.05 & 0.52 & 68.61 \\
Huadian & 10 & 13.83 & 2.03 & 0.53 & 0.32 & 68.01 \\
Huangxian & 14.4 & 30.71 & 3.23 & 0.99 & 0.41 & 50.97 \\
\hline
\end{tabular}

In this experiment nitrogen was used as fluidizing agent for convenience. In the case of commercial large-scale fluidized-bed retorting, the superheated steam or the retorting pyrolysis gas may be used. These agents are all inert in the pyrolysis reaction, therefore $\mathrm{N}$ was considered not to influence experimental results greatly.

\section{Experimental device}

The fluidized-bed reactor of flash pyrolysis has a capacity of $20 \mathrm{~kg} / \mathrm{h}$ with inside diameter $150 \mathrm{~mm}$ and height $1.64 \mathrm{~m}$. The heat required for oil shale pyrolysis was provided by three $4 \mathrm{~kW}$ resistor wires wrapped on the exterior of the fluidized-bed reactor in alumina ceramic tube, and the reactor temperature could be monitored by the thermocouples in three different parts of the reactor. The device could be run uninterruptedly under different parameters conditions. The experimental device is shown in Fig. 1.

The flow sheet of flash pyrolysis of fine particle oil shale mainly consists of raw shale crushing, sieving, flash pyrolysis, separation of quartz sand and

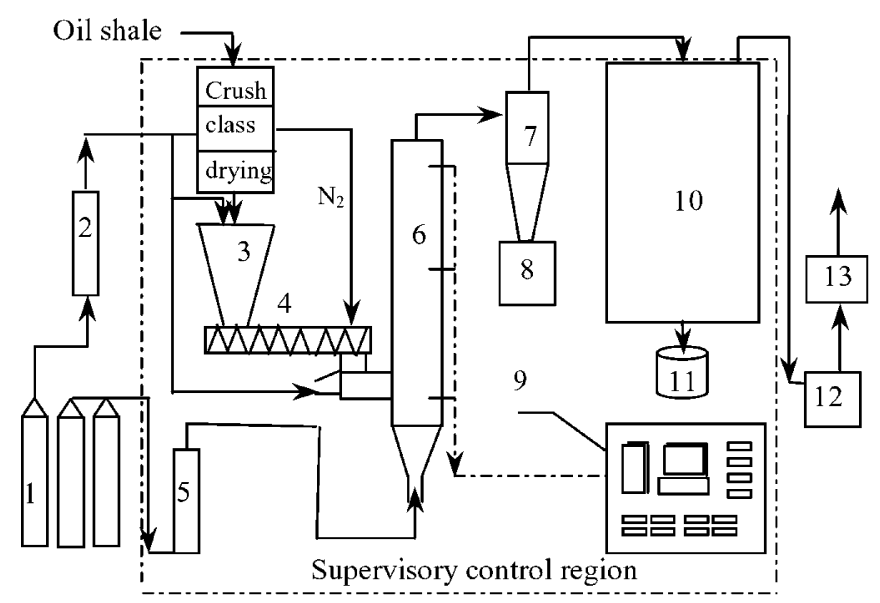

1 - Nitrogen bottle, 2 - Glass rotameter, 3 - Hopper, 4 - Screw feeder, 5 - Flowmeter, 6 - Fluidized-bed reactor, 7 - Cyclone separator, 8 - Shale char collector, 9 - Console, 10 - Condenser, 11 - Shale oil collector, 12 - Lint filter, 13 - Tail gas purifier.

Fig. 1. Experimental device of flash pyrolysis of fine-particle oil shale. 
shale char, cooling of exit gaseous stream and collection of shale oil. Figure 1 indicates two routes into the fluidized bed reactor: one is for oil shale and the other for nitrogen.

As for the nitrogen route, nitrogen is further divided into four streams. The largest one is fluidizing gas which is introduced into the fluidized-bed reactor directly; the other three streams of nitrogen are introduced into the hopper as pressurizing gas, stirring gas and feeding gas, and enter the reactor along with the shale particles. The three streams of nitrogen can guarantee that the oil shale feed enters the reactor successfully. The fine-particle oil shale was heated to the specified reaction temperature instantly in the fluidized-bed reactor at a heating rate about $1000{ }^{\circ} \mathrm{C} / \mathrm{s}$. The two-phase stream leaving the reactor passed through the cyclone separator and entered the condenser where condensable gas was condensed into shale oil and then sent to the shale oil collector. The non-condensable gas and nitrogen entered the tail gas purifier through the lint filter.

As for the solid phase, oil shale particles were fed into the fluidized-bed reactor at a specific feeding rate. The shale char generated from the flash pyrolysis reaction was sent along with the gaseous product into the cyclone separator from which it fell down into the shale char collector [12].

\section{Experimental design}

Confirmation of experimental factors

Literature about the study of fine-particle oil-shale flash pyrolysis producing shale oil is scanty at present. As for the flash pyrolysis process, it can be seen that reaction pressure affects gas residence time, which in turn affects secondary pyrolysis of shale oil that decomposes macromolecules into smaller ones and ultimately affects the distribution of pyrolysis products. A higher pressure increases the residence time of the volatile product which boosts secondary pyrolysis reactions. Consequently it will reduce the yield of shale oil. Therefore, a higher pressure will have a negative effect on oil shale flash pyrolysis. Under a lower pressure, the volatile product can leave the surface of the particles quickly, limiting the occurrence of secondary pyrolysis process and increasing the yield of shale oil. According to the characteristics of fluidized beds [13], the fluidizing medium of nitrogen gas can provide a little positive pressure in the fluidized-bed reactor. It is assumed that this level of pressure is appropriate for the experiment.

Heating rate, which is determined by the size of shale particle, feeding rate and reaction temperature, is an important parameter to classify reaction type. Scott pointed out that the heating rate not only depends on the density of heat flow rate in the experimental process, but also depends on the size and nature of raw material particles $[14,15]$. Maschio also pointed out that a high heating rate is attributed to high reaction temperature, short contact time $(<4 \mathrm{~s})$ and very fine size of particles [16]. A higher heating rate of flash pyrolysis reactor is required by a higher reaction temperature, shorter gas residence time and smaller particles of raw material. Therefore, particle size 
of oil shale, feeding rate and reaction temperature have been identified as the main experimental factors of flash pyrolysis. Besides, according to the design parameters of fluidized bed and relevant literature, it is confirmed that the ranges of the three main factors are as follows: particle size below $0.95 \mathrm{~mm}$; feeding rate between $12-16 \mathrm{~kg} / \mathrm{h}$; reaction temperature 400 $550{ }^{\circ} \mathrm{C}[17,18]$. In fact, many other factors also affect the yield of shale oil in flash pyrolysis experiments, but the factors which have already been confirmed via preliminary experiments are shown in Table 2.

\section{Table 2. Values of fixed factors}

\begin{tabular}{l|l|}
\hline Fluidizing gas volume & $15-20 \mathrm{~m}^{3} / \mathrm{h}$ \\
Pressurizing gas volume & $2.4-3 \mathrm{~m}^{3} / \mathrm{h}$ \\
Feeding gas volume & $3-3.3 \mathrm{~m}^{3} / \mathrm{h}$ \\
Stirring gas volume & $3.6-4 \mathrm{~m}^{3} / \mathrm{h}$ \\
Flow rate of condenser water & $2.74 \times 10^{-3} \mathrm{~m} / \mathrm{s}$ \\
Size of quartz sand particles & $0.4-0.67 \mathrm{~mm}$ \\
\hline
\end{tabular}

\section{Experimental factors and levels}

Table 3 lists the schedule of the orthogonal test with key parameters including reaction temperature $(A)$, feeding rate $(B)$, particle size $(C)$ and the blank column $(D)$ selected as four factors, and every factor has three levels to be optimized. Shale oil yields are taken as the index points to evaluate maximum outputs under different factors and levels. Analyses of the fourth column - the blank column - were also made to guarantee that no factors were missing. If the blank column had a great effect on the yield, it would imply that some important factors had not been considered in the study. If not, it could be concluded that all the important factors have been taken into account.

Table 3. Factors and levels selected for orthogonal experiment

\begin{tabular}{|c|c|c|c|c|}
\hline Level & $\begin{array}{c}A \\
\text { Reaction } \\
\text { temperature, }{ }^{\circ} \mathrm{C}\end{array}$ & $\begin{array}{c}B \\
\text { Feeding rate, } \\
\mathrm{kg} / \mathrm{h}\end{array}$ & $\begin{array}{c}C \\
\text { Particle size, } \\
\mathrm{mm}\end{array}$ & $\begin{array}{c}D \\
\text { Blank column }\end{array}$ \\
\hline 1 & $400-450$ & 12 & $0-0.47$ & \\
2 & $450-500$ & 14 & $0.47-0.67$ & \\
3 & $500-550$ & 16 & $0.67-0.95$ & \\
\hline
\end{tabular}

\section{Results and discussion}

\section{Results of orthogonal experiments}

Each combination in the orthogonal table was investigated. Each combination needed $4 \mathrm{~kg}$ oil shale, and the experimental results are shown in Table 4. 
Table 4. Detailed scheme of orthogonal test and properties of the products

\begin{tabular}{|c|c|c|c|c|c|c|c|c|c|}
\hline $\begin{array}{c}\text { Series } \\
\text { No }\end{array}$ & $\begin{array}{c}\text { Factor } \\
A\end{array}$ & $\begin{array}{c}\text { Factor } \\
B\end{array}$ & $\begin{array}{c}\text { Factor } \\
C\end{array}$ & $\begin{array}{c}\text { Factor } \\
D\end{array}$ & $\begin{array}{c}\text { Shale } \\
\text { char } \\
\text { weight, } \\
\mathrm{kg}\end{array}$ & $\begin{array}{c}\text { Shale } \\
\text { oil } \\
\text { weight, } \\
\mathrm{kg}\end{array}$ & $\begin{array}{c}\text { Shale } \\
\text { oil } \\
\text { density, } \\
\mathrm{g} / \mathrm{cm}^{3}\end{array}$ & $\begin{array}{c}\text { Shale } \\
\text { oil } \mathrm{pH}\end{array}$ & $\begin{array}{c}\text { Shale oil } \\
\text { viscosity, } \\
\mathrm{mPa} \cdot \mathrm{s} \\
\left(20^{\circ} \mathrm{C}\right)\end{array}$ \\
\hline 1 & 1 & 1 & 1 & 1 & 2.64 & 0.1891 & 0.8794 & 4.48 & 17 \\
2 & 1 & 2 & 2 & 2 & 2.58 & 0.1996 & 0.8613 & 4.66 & 16 \\
3 & 1 & 3 & 3 & 3 & 2.44 & 0.1775 & 0.8541 & 4.86 & 17 \\
4 & 2 & 1 & 2 & 3 & 2.66 & 0.1876 & 0.8584 & 4.62 & 15 \\
5 & 2 & 2 & 3 & 1 & 2.51 & 0.1929 & 0.8541 & 4.14 & 16 \\
6 & 2 & 3 & 1 & 2 & 2.76 & 0.2042 & 0.8601 & 4.92 & 17 \\
7 & 3 & 1 & 3 & 2 & 2.33 & 0.1656 & 0.8621 & 3.91 & 14 \\
8 & 3 & 2 & 1 & 3 & 2.73 & 0.2031 & 0.8886 & 4.57 & 16 \\
9 & 3 & 3 & 2 & 1 & 2.62 & 0.1891 & 0.8610 & 4.29 & 15 \\
\hline
\end{tabular}

The yields of shale oil under all operating conditions were analyzed by the software of DPS Variance Analysis. Table 5 indicates that particle size of oil shale is the most important factor, the second being feeding rate and the third being reaction temperature. The blank column hardly has any effect, which suggests there are no other factors than those identified in this study which may affect the results of the experiments. The optimum combination of the orthogonal experiment is $A_{2} B_{2} C_{1}$.

It can be seen that the optimum combination was as follows: particle size of oil shale less than $0.47 \mathrm{~mm}$; feeding rate $14 \mathrm{~kg} / \mathrm{h}$ (residence time $11 \mathrm{~min}$.) and reactor temperature $450-500{ }^{\circ} \mathrm{C}$ (Tables 4 and 5 and Fig. 4). The verification experiment was completed according to the optimum combination, and the result is as follows:

Shale feed $4 \mathrm{~kg}$; shale char $2.73 \mathrm{~kg}$; shale oil yield $0.2051 \mathrm{~kg}$; density $0.8613 \mathrm{~g} / \mathrm{cm}^{3} ; \mathrm{pH} 4.10$; viscosity $16 \mathrm{mPa} \cdot \mathrm{s}$.

Table 5. Variance analysis of orthogonal test

\begin{tabular}{|c|c|c|c|c|c|}
\hline $\begin{array}{l}\text { Variation } \\
\text { source }\end{array}$ & Squariance & $\begin{array}{l}\text { Degree of } \\
\text { freedom }\end{array}$ & $\begin{array}{l}\text { Mean } \\
\text { square }\end{array}$ & $F$ value & Significance level \\
\hline $\begin{array}{l}\text { Reaction } \\
\text { temperature }\end{array}$ & 0.00013 & 2 & 0.00006 & 89.20094 & 0.01109 \\
\hline Feeding rate & 0.00047 & 2 & 0.00024 & 335.02198 & 0.00298 \\
\hline Particle size & 0.00063 & 2 & 0.00032 & 445.54631 & 0.00224 \\
\hline Blank & 0.00000 & 2 & 0.00000 & & \\
\hline Error & 0.00000 & 2 & 0.00000 & & \multirow{2}{*}{$\begin{array}{c}\text { Relation between } \\
\text { primary and } \\
\text { secondary factors } \\
C B A\end{array}$} \\
\hline Summation & 0.00123 & & & & \\
\hline$Y_{\mathrm{j} 1}$ & 0.5662 & 0.5423 & \multirow{3}{*}{\multicolumn{2}{|c|}{$\begin{array}{l}0.5964 \\
0.5763 \\
0.5360\end{array}$}} & \multirow{3}{*}{$\begin{array}{c}\text { Optimum } \\
\text { combination } \\
A_{2} B_{2} C_{1}\end{array}$} \\
\hline$Y_{\mathrm{i} 2}$ & 0.5847 & 0.5956 & & & \\
\hline$Y_{\mathrm{i} 3}$ & 0.5578 & 0.5708 & & & \\
\hline
\end{tabular}


The result suggests that the orthogonal verification experiment yields more shale oil than any other combination, and the yield of shale oil is $5.13 \%$.

\section{Results of one-factor verification experiment}

The optimum combination range, which is confirmed via orthogonal experiment, may be relatively small. It may lead to experimental errors. In order to reduce errors to a minimum, the one-factor verification experiment which would fix the range of two optimal factors of orthogonal experiment and change the range of another optimal factor was done. It would verify whether the new optimum combination was the same as the optimum combination of the orthogonal experiment, which could test the accuracy of experiment. The results of one-factor verification experiments are shown in Table 6. It shows that the optimum combination which results in the highest yield of shale oil in the one-factor verification experiments is the same as the optimum combination of the orthogonal experiment.

Table 6. Oil yield of one-factor verification experiment (shale feed $4 \mathbf{k g}$ )

\begin{tabular}{|c|c|c|c|l|l|l|}
\hline No. & $\begin{array}{c}\text { Reaction } \\
\text { temperature, } \\
{ }^{\circ} \mathrm{C}\end{array}$ & $\begin{array}{c}\text { Feeding rate, } \\
\mathrm{kg} / \mathrm{h}\end{array}$ & $\begin{array}{c}\text { Particle size, } \\
\mathrm{mm}\end{array}$ & $\begin{array}{c}\text { Shale } \\
\text { char, kg }\end{array}$ & $\begin{array}{c}\text { Shale oil, } \\
\mathrm{kg}\end{array}$ & $\begin{array}{c}\text { Oil yield, } \\
\%\end{array}$ \\
\hline 1 & $450-500$ & 14 & $0-0.3$ & 2.73 & 0.2052 & 5.13 \\
2 & $450-500$ & 14 & $0.3-0.47$ & 2.71 & 0.2051 & 5.1275 \\
3 & $450-500$ & 14 & $0.47-0.61$ & 2.68 & 0.1991 & 4.9775 \\
4 & $450-500$ & 14 & $0.61-0.67$ & 2.60 & 0.1954 & 4.885 \\
5 & $450-500$ & 14 & $0.67-0.78$ & 2.62 & 0.1930 & 4.825 \\
6 & $450-500$ & 14 & $0.78-0.95$ & 2.58 & 0.1811 & 4.5275 \\
7 & $450-500$ & 10 & $0-0.3$ & 2.64 & 0.1890 & 4.725 \\
8 & $450-500$ & 12 & $0-0.3$ & 2.51 & 0.1990 & 4.975 \\
9 & $450-500$ & 14 & $0-0.3$ & 2.69 & 0.2052 & 5.13 \\
10 & $450-500$ & 16 & $0-0.3$ & 2.76 & 0.2042 & 5.105 \\
11 & $450-500$ & 18 & $0-0.3$ & 2.54 & 0.2001 & 5.0025 \\
12 & $450-500$ & 20 & $0-0.3$ & 2.46 & 0.1951 & 4.8775 \\
13 & $250-300$ & 14 & $0-0.3$ & 2.73 & 0.1994 & 4.985 \\
14 & $300-350$ & 14 & $0-0.3$ & 2.59 & 0.2002 & 5.005 \\
15 & $350-400$ & 14 & $0-0.3$ & 2.66 & 0.2016 & 5.04 \\
16 & $400-450$ & 14 & $0-0.3$ & 2.65 & 0.2045 & 5.1125 \\
17 & $450-500$ & 14 & $0-0.3$ & 2.55 & 0.2052 & 5.13 \\
18 & $500-550$ & 14 & $0-0.3$ & 2.69 & 0.2031 & 5.0775 \\
\hline
\end{tabular}

\section{Analysis of experimental results}

\section{Particle size}

The physical phenomena of flash pyrolysis process of oil shale are mainly heat transfer and mass transfer, and particle size of oil shale plays an important role in both cases. The change of particle size will affect the 
heating rate of oil shale as well as the transmission of the volatile product. Thus, it will determine the flash pyrolysis behavior of oil shale in the fluidized-bed reactor. According to the results of the one-factor verification experiments, the correlation curve of oil shale particle size and shale oil yield is figured out and shown in Fig. 2. It can be seen that smaller oil shale particles yield more shale oil in flash pyrolysis experiments as determined by the nature of flash pyrolysis. At the same fluidizing-gas volume, the center of smaller particles could be heated instantly, so the volatile product would escape rapidly from its interior and the gas residence time is very short. This results in a maximum shale oil yield. On the contrary, when oil shale particles were much larger, incomplete pyrolysis reaction would take place, and the fluidizing gas would blow into the shale char collector the oil shale particles which had not reacted completely. In addition, the volatile product from larger particles diffused slowly and gas residence time was longer. That would lead to the secondary pyrolysis reaction, reducing shale oil yield. Thus particle size of oil shale plays a decisive role in the pyrolysis reaction of oil shale in the fluidized-bed reactor. It could also be seen that the increase in shale oil yield was small when particle size was smaller than $0.47 \mathrm{~mm}$. From the perspective of economics, it is of no value to further reduce particle size of oil shale. In the one-factor experiments, oil shale particles smaller than $0.3 \mathrm{~mm}$ were used because the goal of the experiment was to determine the optimum parameters of the flash pyrolysis process in the fluidized-bed reactor.

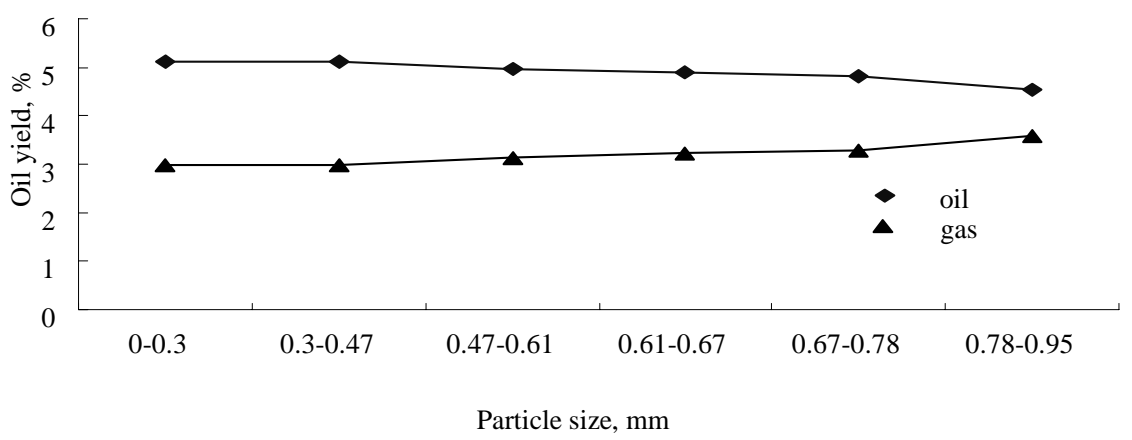

Fig. 2. Shale oil yield depending on particle size.

\section{Feeding rate}

Increasing of the oil shale feeding rate is also an effective means that shortens gas residence time. The reason is that it increases the output of the volatile product in time unit, which leads to the decrease of gas residence time. There should be an optimal feeding rate for a specific heating power and feeding device in the system, because if the feeding rate is too high, the 
temperature of the fluidized-bed reactor will reduce rapidly, leading to incomplete reaction of oil shale. However, a low feeding rate will increase gas residence time, thus may lead to secondary pyrolysis reactions. Therefore an inappropriate feeding rate will reduce shale oil yield. In order to ensure the accuracy of the one-factor verification experiment, the feeding rates of $10,12,14,16,18$ and $20 \mathrm{~kg} / \mathrm{h}$, were selected. The correlation curve of oil shale feeding rate and shale oil yield is shown in Fig. 3, and the residence time of oil shale in the reactor is calculated according to the content of shale char and feeding rate. Figure 4 shows the relationship between the residence time of feed and feeding rate. It can be seen that shale oil yield reaches a maximum and that of the non-condensable gas reaches a minimum when the feeding rate is $14 \mathrm{~kg} / \mathrm{h}$ (corresponding to the residence time of feed about $11 \mathrm{~min}$.), which is the same as the optimum feeding rate of the orthogonal experiment. It shows that the volatile product has to some extent undergone secondary pyrolysis reaction when the feeding rate is less

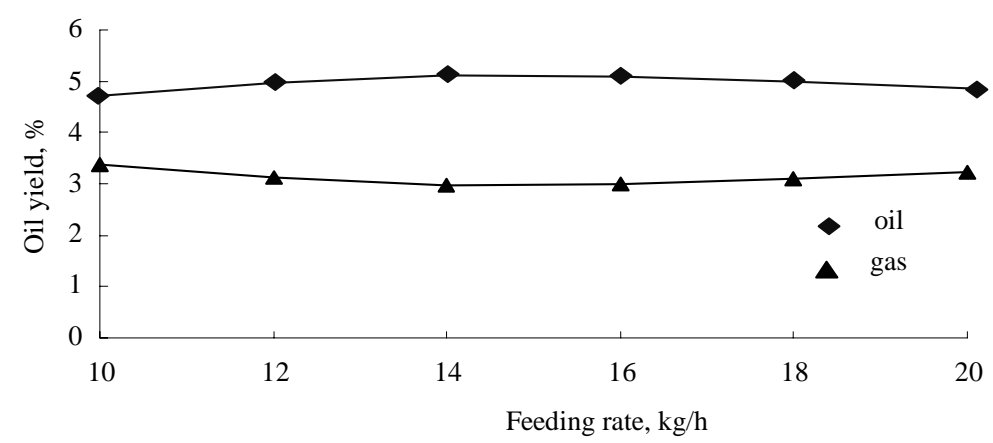

Fig. 3. Shale oil yield depending on feeding rate.

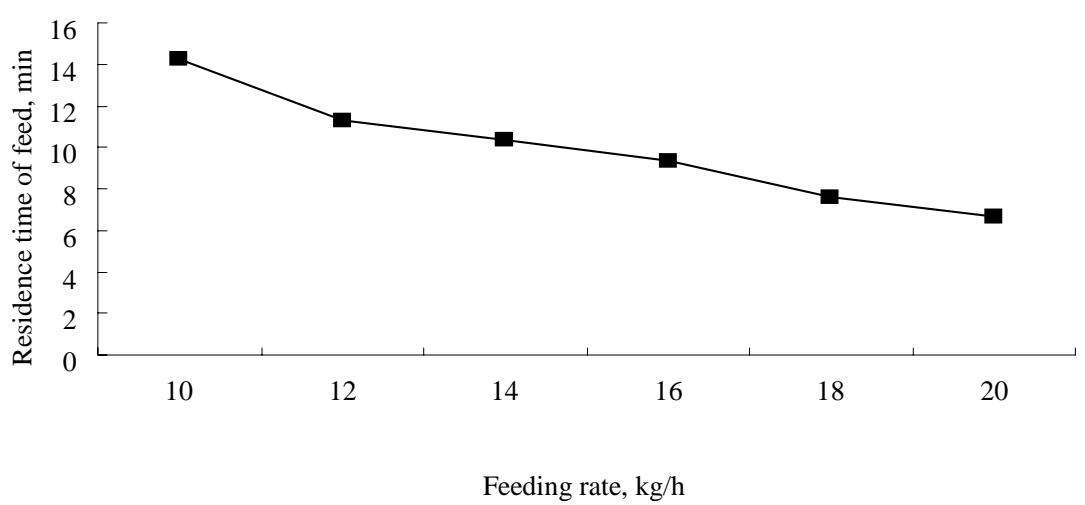

Fig. 4. Residence time depending on feeding rate. 
than $14 \mathrm{~kg} / \mathrm{h}$, despite the fact that pyrolysis of the oil shale has ended. When feeding rate is higher than $14 \mathrm{~kg} / \mathrm{h}$, shale oil yield gradually reduces with increasing feeding rate. The reason is that a higher feeding rate reduces the temperature in the fluidized-bed reactor rapidly, which leads to incomplete pyrolysis. At the same time, in the course of the experiment, incomplete pyrolysis of oil shale can be observed obviously in the shale char collector when feeding rate is higher than $18 \mathrm{~kg} / \mathrm{h}$. That feeding rate was another important effect factor, second only to particle size was concluded analyzing the results of the orthogonal experiments. Therefore a reasonable feeding rate is very important in the process of oil shale pyrolysis experiment.

\section{Reaction temperature}

Reaction temperature is also one of the main factors which determine oil shale pyrolysis process and final composition of the product. Different reaction temperatures have different effects on the pyrolysis reaction of oil shale in the fluidized-bed reactor. The conclusion that the optimum reaction temperature is $450-500{ }^{\circ} \mathrm{C}$ was drawn from orthogonal experiments. This conclusion was the same as the one drawn from the one-factor verification experiments. In order to better explain the regularity that reaction temperature affects shale oil yield, the corresponding relationship is shown in Fig. 5. It can be seen that shale oil yield gradually increases in the range of reaction temperature from $250{ }^{\circ} \mathrm{C}$ to $450{ }^{\circ} \mathrm{C}$, and a maximum yield is obtained at $450-550{ }^{\circ} \mathrm{C}$. The trend line shows that oil shale particles cannot be heated to the center instantly in the fluidized-bed reactor when reaction temperature is lower than $450{ }^{\circ} \mathrm{C}$. This will in turn lead to incomplete reaction in which the volatile product within oil shale cannot escape completely. However, shale oil yield begins to decrease when reaction temperature is higher than $500{ }^{\circ} \mathrm{C}$. This may be caused by the special physical and chemical structure of oil shale. At the same time, a higher temperature

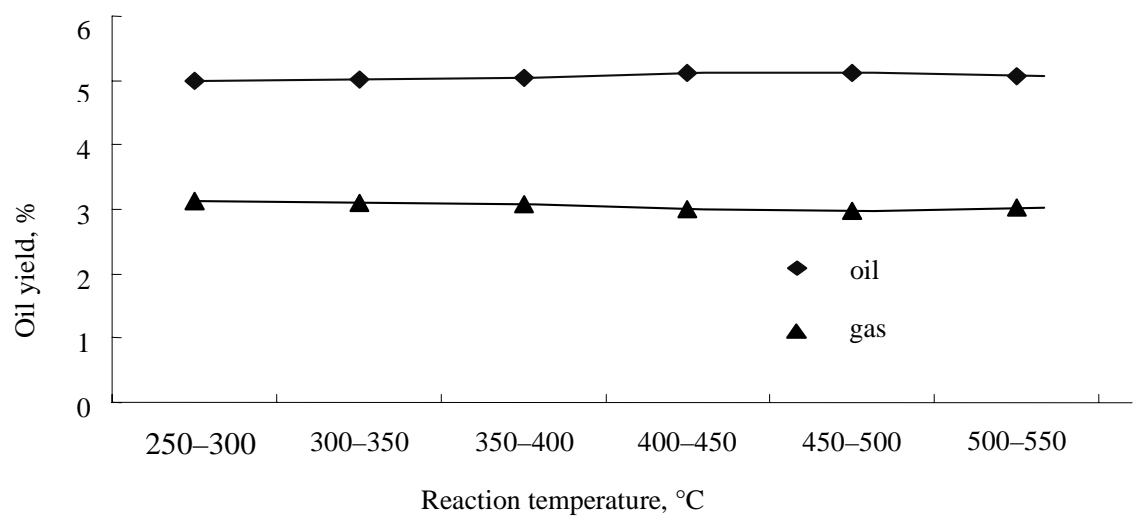

Fig. 5. Shale oil yield depending on reaction temperature. 
will also intensify secondary pyrolysis reactions, and, consequently, reducing shale oil yield. It is concluded from the orthogonal experiments that the effect of reaction temperature is less strong than those of particle size and feeding rate. Nevertheless, since reaction temperature determines the extent of pyrolysis reaction, it is also necessary to control reaction temperature in the process of oil shale flash pyrolysis experiment.

\section{Analysis of shale oil}

Shale oil is a brown paste with an irritating odor at normal temperature. We measured and analyzed shale oil density, $\mathrm{pH}$ and viscosity. The results are given in Table 4. It can be seen that the changes of such values under various operating conditions are small, which shows that shale oil characteristics were relatively stable in the flash pyrolysis experiments.

\section{Conclusions}

Shale oil yield is low as $5.13 \%$ under the conditions of optimum process parameters in flash pyrolysis experiment, however, due to the fact that the oil shale in Fushun is a by-product of coal mining. Therefore the oil shale mining cost is very low. Now in the Fushun shale oil plant lump oil shale has been processed in Fushun Type retorts for producing shale oil for more than sixty years profitably with the lower limit of Fischer assay oil yield of 5\%. Therefore fine particles are also worthy to be processed, and flash pyrolysis experiment could provide useful data for fluidized-bed pyrolysis, which could be potentially an effective means of utilizing raw shale screenings of the retorting plant.

Particle size, feeding rate and reaction temperature determined the pyrolysis behaviour of oil shale in the fluidized-bed reactor. Their optimum combination minimized secondary pyrolysis of the volatile product, leading to the highest shale oil yield.

Basing on the shale oil yields under various operating conditions in the orthogonal experiments and one-factor verification experiment, it was concluded that the optimum combination was as follows: particle size of oil shale less than $0.47 \mathrm{~mm}$; feeding rate $14 \mathrm{~kg} / \mathrm{h}$ (residence time of feed $11 \mathrm{~min}$ ), and reactor temperature $450-500{ }^{\circ} \mathrm{C}$. The optimum reaction temperature (450$\left.500^{\circ} \mathrm{C}\right)$ is lower than the final pyrolysis temperature $\left(600^{\circ} \mathrm{C}\right)[19]$ of oil shale.

\section{Acknowledgments}

The authors gratefully acknowledge the Institute of Comprehensive Utilization of Waste, Jilin Agricultural University for its technical support. This research was supported by Jilin Province Science and Technology Agency Key Projects under the Contract No. 20030320. 


\section{REFERENCES}

1. Hepbasli, A. Oil shale as an alternative energy source // Energ. Source. 2004. Vol. 26, No. 2. P. 107-118.

2. Adnan, A. H., Mohammad, A. H., Awni, A. O., Mamdoh, A. Effect of demineralization of El-Lajjun Jordanian oil shale on oil yield // Fuel Process. Technol. 2009. Vol. 90, No. 6. P. 818-84.

3. Dyni, J. R. Geology and resources of some world oil- shale deposits // Oil Shale. 2003. Vol. 20, No. 3. P. 193-252.

4. Qian, J. L., Wang, J. Q., Li, S. Y. Oil shale development in China // Oil Shale. 2003. Vol. 20, No. 3S. P. 356-359.

5. Ots, A. Oil shale as a power fuel // Oil Shale. 2005. Vol. 22, No. 4S. P. 367-368.

6. Ehinola, O.A., Sonibare, O.O., Akanbi, O.A. Economic evaluation, recovery techniques and environmental implications of the oil shale deposit in the Abakaliki anticlinorium, Southeastern Nigeria // Oil Shale. 2005. Vol. 22, No. 1. P. 5-19.

7. Abu-Qudais, M., Jaber, J. O., Sawalha, S. Kinetics of pyrolysis of Attarat oil shale by thermogravimetry // Oil Shale. 2005. Vol. 22, No. 1. P. 51-63.

8. Zhang, Z. Z. Construction of oil shale power plant to develop new energy in Guangdong, China // Guangdong Electric Power. 1991. Vol. 15, No. 6. P. 7-11 [in Chinese].

9. Williams, P. F. V. Oil shales and their analysis // Fuel. 1983. Vol. 62, No. 7. P. 756-771.

10. Zhang, O. M. Several typical oil shale retorting technology//Journal of Jinlin University (Earth Science Edition). 2006. Vol. 36, No. 2. P. 1020-1023 [in Chinese].

11. Liu Zhaojun, Dong Qingshui. The situation of oil shale resources in China // Journal of Jinlin University (Earth Science Edition. 2006. Vol. 36, No. 6. P. 869876 [in Chinese].

12. Wang, S. R., Luo, Zh. Y., Dong, L. J. Flash pyrolysis of biomass for bio-oil in a fluidized bed reactor // Acta Energiae Solaris Sinica. 2002. Vol. 23, No.1. P. 5-8.

13. Roberts, M. J., Rue, D. M., Lau, F. S. Pressurized fluidized-bed hydroretorting of raw and beneficiated Eastern oil shales // Fuel. 1992. Vol. 71, No. 12. P. 14331439.

14. $X u, B . J ., \quad L i, M . L ., \quad Z e n g, Z h$. Rotating cone flash pyrolysis of biomass study // Environment Process Engineering. 1999. Vol. 17, No. 5. P. 71-74.

15. Scott, D. S., Piskorz, J. The flash pyrolysis of aspen-poplar wood // Can. J. Chem. Eng. 1982. Vol. 60, No. 4. P. 666-674.

16. Maschio, G., Koufopanos, C., Lucchesi, A. Pyrolysis, a promising route for biomass utilization // Bioresource Technol. 1992. Vol. 42, No. 3. P. 219-231.

17. Harada, K. Research and development of oil shale in Japan // Fuel. 1991. Vol.70, No. 11. P. 1330-1335.

18. Dung, N. V. Yields and chemical characteristics of products from fluidized bed steam retorting of Condor and Stuart oil shales: effect of prolysis temperature // Fuel. 1990. Vol. 69, No. 3. P. 368-376.

19. Han, X. X., Jiang, X. M., Cui, Z. G., Zhang, C. Q. Pyrolysis behavior of oil shale semi-coke// Chinese Journal of Chemical Engineering. 2006. Vol. 57, No. 6. P. 126-130.

Presented by E. Volkov

Received March 18, 2010 